УДК 811.111 '42:001.8

\title{
THE PRAGMATICS OF POLITENESS IN THE AMERICAN TV TALK SHOW PIERS MORGAN LIVE
}

\author{
Mariya Fedyna \\ Ivan Franko National University of Lviv, \\ 1, Universytetska St., Lviv, 79000, Ukraine \\ mariya.fedyna@gmail.com
}

This paper addresses the issue of linguistic realization of politeness strategies in the American talkshow: Piers Morgan Live. The analysis of the data has been carried out within the politeness framework suggested by Brown and Levinson. The corpus data analyzed includes fifteen interviews selected from Piers Morgan Live, CNN. The analysis involves chosen interview extracts which contain verbal exchanges in which positive and negative politeness strategies are deployed. On the basis of the analyzed interviews, the study strives to examine the communicative behavior of Piers Morgan as an interviewer. The study explores the notions of politeness, face and face threatening acts (FTAs). In addition, we consider whether the politeness strategies identified in Brown and Levinson's politeness theory can be found in another discourse type, namely the talk show discourse type. Firstly, we will offer an analysis of the linguistic realization of positive politeness and then an analysis of negative politeness strategies. Hence, the analysis reveals that politeness theory seems to be relevant for the study of communicative behavior of the interviewer in the discourse of television interviews. Although both the strategies of positive and negative politeness are deployed in Piers Morgan's communicative behavior, positive politeness strategies seem to prevail in the communicative behavior of the interviewer.

Consequently, it seems reasonable to assume that the strategies of positive politeness which are used contribute to (a) closing the social distance between interlocutors; (b) putting the interviewees at ease by creating a friendly atmosphere to allow them to 'open up'. Moreover, more than one strategy is realized within each utterance. More importantly, we tend to believe that the strategies, deployed in the communicative behavior of the interviewer, are all strategic to Piers Morgan's extralinguistic goal of having a good interview.

Keywords: face, positive face, negative face, face-threatening acts, positive politeness, negative politeness, speech strategies, (im)politeness.

\section{Introduction}

The given paper suggests how Penelope Brown and Stephen C. Levinson's Politeness Theory - a well known and widely acknowledged theory in linguistics - can contribute to the study of talk show discourse. The analysis of the data has been carried out through the prism of Penelope Brown and Stephen C. Levinson's Politeness Theory. The scholars base their theory on the notion

(C) M. Fedyna, 2016 
of "face", "the public self-image that every member of a society wants to claim for himself", that was derived from that of Goffman and the English folk term (Brown \& Levinson, 1987, p. $61 ; 4 ; 6)$.

In contradistinction to Goffman's view of face, Brown and Levinson (1987) redefined face in terms of basic wants, "which every member knows every other member desires, and which in general it is in the interests of every member to partially satisfy" (Brown \& Levinson, 1987, p. 62).

Brown and Levinson (1987) note that the components of face may be related as follows: "positive face - the want of every member that his wants be desirable to at least some others, by positive face they understand the positive consistent self-image or 'personality' (crucially including the desire that this self-image be liked, admired, cared about, understood, listened to, approved of, and so forth); negative face - the want of every 'competent adult member' that his actions be unimpeded by others; the basic claim to freedom of action and freedom from imposition. Therefore, positive politeness is oriented toward the positive face of $\mathrm{H}$, the positive self-image that he claims for himself. On the other hand, negative politeness is oriented mainly toward partially satisfying (redressing) H's negative face, his basic want to maintain claims of territory and self-determination" (Brown \& Levinson, 1987, p. 62).

Although during any social interaction there is a need to maintain faces of each other, facethreatening acts (FTAs) frequently occur. According to Brown and Levinson, a face threatening act is an act that damages the face of the addressee or the speaker by acting in opposition to the wants and desires of the other. These acts may be both verbal and non-verbal. Moreover, there can be several FTAs associated with a single utterance. Both positive and negative faces may be threatened. In order to save the face of each other during a social interaction, Brown and Levinson outlined four basic types of politeness strategies: bald on-record, negative politeness, positive politeness, and off-record (indirect). In our opinion, communicative behavior of the speaker is a wide concept, which embraces both positive and negative face. Therefore, the purpose of this paper is to study the communicative behavior of Piers Morgan applying Brown and Levinson's politeness theory to the analysis of Piers Morgan Live talk-show interviews. Likewise, we will attempt to observe what type of politeness strategies seems to be prevalent in Piers Morgan's communicative style and how politeness strategies used by the interviewer are realized on linguistic and cognitive levels.

\section{The data}

The data for the present study has been taken from fifteen interviews conducted with people from the spheres of politics, cinematography and television (Oprah Winfrey, Whoopi Goldberg, Eva Longoria, Charlize Theron, Howard Stern, Sharon Stone, Ann Coulter, Simon Cowell, Rod Stewart, Morgan Freeman, Beyonce, Heidi Klum, Russel Brand, 50Cent and Barbra Streisand) (CNN Transcripts. Piers Morgan Tonight ). The period of the interview selection from "Piers Morgan Live” is from 2011 till 2013. Extracts were chosen from the interviews on the basis that they appeared to contain verbal exchanges in which positive and negative politeness strategies are deployed.

"Piers Morgan Live" (formely known as "Piers Morgan Tonight") is an American talk show on CNN, hosted by Piers Morgan. Piers Morgan has had a long career in journalism in the United Kingdom as a newspaper editor for The Mirror, as a full-time host of BBC shows like Tabloid Tales and as a judge on America's Got Talent in the USA. The show premiered on January 17, 2011 and filled the former Larry King Live timeslot. The talkshow is known for frank and deep conversations with American celebrities and public figures. Morgan has attracted criticism particularly for his TV work, with claims that he is "smarmy," "arrogant," "self-satisfied," and "too 
full of himself". However, he says he has a "very personal style" of interviewing familiar to British audiences that he hopes will be a pleasant surprise to Americans (Piers Morgan Live). As one might imagine these characteristics can be a contentious issue in terms of Piers Morgan's communicative behavior. It is for these reasons that this CNN talkshow was chosen.

\section{Analysis: linguistic realization of positive politeness strategies}

As Brown and Levinson (1987) note "positive politeness is redress directed to the addressee's positive face, his perennial desire that his wants should be thought of as desirable. Redress consists in partially satisfying that desire by communicating that one's own wants (or some of them) are in some respects similar to the addressee's wants" (Brown \& Levinson, 1987, p. 101). What is more, positive-politeness utterances are used as a kind of metaphorical extension of intimacy, to imply common ground or sharing of wants to a limited extent even between strangers who perceive themselves, for the purposes of the interaction, as somehow similar, which appears to be helpful while studying the communicative behavior of the interviewer as sometimes we have almost "strangers" in the studio. For the same reason, Brown and Levinson add that positive-politeness strategies are employed as "a kind of social accelerator", where S, in using them, indicates that he wants to 'come closer' to H (Brown \& Levinson, 1987, p. 103).

On the basis of positive politeness strategies suggested by Brown and Levinson and from our personal observations, we have singled out three groups of positive politeness strategies, on the basis that each group shares some common features. However, it should be made clear that these groups are not established categories as they are formed from our own observations and may remain a contentious issue for researchers. What is more, the task of this study is not to discuss all strategies in detail, but to focus on those utterances, which seem to contain both positive and negative politeness strategies.

1. The first group involves strategies that are intended to demonstrate attention to the interlocutor, his interests, desires, needs, and show attention to personal traits of the interlocutor, so to speak interviewer takes notice of aspects of interviewee's condition (noticeable changes, remarkable possessions, anything which looks as though interviewee would want interviewer to notice or approve of).

Note the following examples:

MORGAN to WINFREY: What I like about you is there's always tough love from you. // I love that honesty about you. Here Morgan notices Oprah's honesty and by complimenting her, approves of it.

MORGAN to THERON: All your stuff is heavy. This is why I like you. I like that about you as an actress. Here Piers attends to his guest by admiring her for her career. However, what is of special interest here is that the utterance "All your stuff is heavy" is actually a FTA, which implies that Theron is not offered light roles, but it turns into positive politeness by further utterances.

We also refer the strategy of exaggeration to the first group, as the host usually demonstrates the exaggerated attention, interest, approval, sympathy with the interlocutor, in order to show a keen interest.

Interestingly enough, according to Brown and Levinson (1987), linguistic realizations of positive politeness are in many respects simply representative of the normal linguistic behavior between intimates. Perhaps the only feature that distinguishes positive-politeness redress from normal everyday intimate language behavior is an element of exaggeration, which serves as a marker of the face-redress aspect of positive-politeness expression (Brown \& Levinson, 1987, p. 101). 
Morgan uses the strategy of exaggeration when he addresses Oprah Winfrey:

MORGAN: There are two people I would never swear in front of. One is her majesty the queen, and the other is Oprah Winfrey. You are the American queen. WINFREY: Thank you for that. I'll accept that.

Morgan clearly wants to satisfy the positive image of Oprah by complimenting her, using the exaggeration strategy. He makes a comparison between Winfrey and the Queen. Besides, we should not forget that the word 'queen' has a very positive connotation in Great Britain, thus it means that Oprah is really good at what she is doing. However, the exaggeration is so striking in the given utterance that it turns into flattery, as calling somebody 'a queen' is clear flattery, which is, in fact, a face-threatening act (FTA).

However, we tend to believe that in Piers Morgan's cases FTAs may be well disguised and seem to express a positive intention at first sight. Nevertheless, they may have an absolutely different meaning in the context. For instance, when Morgan compliments Winfrey and asks her if she likes being famous (MORGAN: You are the nearest thing America's got. Do you feel regal? Do like being famous?) an experienced hostess sees an implicit meaning and intention of this question and replies that this is a provocative question, which she will not answer (WINFREY: That's a good question, provocative question. I'll give you credit for that. However, I'm not going to give you the answer that you want, and that is, you know, a yes or a no, like, gee, I love being famous), as one way or another she would lose her face.

As well as in the example with 50 Cent:

MORGAN: I've never been surprised by anybody. You're one of the squeakiest cleanest men I've ever met.

Analyzing the given utterance, we can see a vivid exaggeration, as almost every day Morgan meets a lot of famous people, in order to interview them, so that sounds totally unbelievable that nobody has surprised him before by being "sober" and "clean" in terms of staying away from drugs and alcohol. In this case, Piers wants to attend to his guest by paying tribute to him, thus satisfying the wants of the interlocutor's positive face.

In the words of Larina, much attention should be paid to the fact that exaggeration is an important feature of English communicative behavior, especially in live communication. Linguistic exaggeration is manifested by lexical superlatives, repetitions, as well as intensifying modifiers such as absolutely, completely, and the like (Laryna, 2009). Thus expressions like unbelievable // amazing / / fantastic // incredible // extraordinary // marvelous, etc. abound in Piers Morgan's communicative behavior. Besides, according to Brown and Levinson, such words may abound in any positively polite talk. However, on the basis of our observations we tend to assume that the expressions (mentioned above) might be "empty" in their meanings, and in our opinion, might not be related to the strategy of exaggeration suggested by the scholars.

Our first group also involves the strategy of gift-giving to $\mathbf{H}$, which is considered by Brown and Levinson (1987) to be the classic positive-politeness action, but what is important, not only tangible gifts (which demonstrate that $\mathrm{S}$ knows some of H's wants and wants them to be fulfilled), but human-relations wants such as sympathy, understanding, cooperation, and so forth are satisfied. Hence we call this strategy "communicative gift-giving".

Note the example when Morgan refers to Whoopi Goldberg showing his sympathy and understanding, when she shares her ill-fated love affairs with Morgan, he tries his best to support her in a 'communicative' way - MORGAN to GOLDBERG: I feel quite sad for you; in such a way, Morgan gives her a kind of 'communicative' gift in the form of his compassion/sympathy. 
Interestingly enough, it is done to make the guest trust the interviewer like a friend and help him/ her open up for the further conversation.

2. The second group of strategies includes attempts to claim common point of view, common opinions, attitudes, knowledge and empathy with the interlocutor by means of seeking agreement, avoiding disagreement, joking.

The communicative goal of these strategies is to create and maintain harmony in the process of communication; to develop a good rapport with the interlocutor and to show solidarity.

For example, considering the utterance when Morgan refers to Beyonce:

MORGAN to BEYONCE: Wow, you belted that. I mean, waiting before you went to sing that, knowing the background, knowing what you've known about your parents, the struggle they've had to come through, like so many African-Americans in America and then Barack Obama has become president, this sea change. And on the night that America celebrates, you are selected to sing.

BEYONCE: Right.

Analyzing these phrases, we can see that Morgan wants to say that he realizes what Beyonce felt at the moment of Obama's inauguration and what she had to go through before going on stage, like all her previous experience flashed in her head, namely: the struggling situation her parents being African-Americans went through. At the same time, he pays her a compliment, emphasizing that among a large number of artists she was the one chosen to sing during such a special event for America.

Or as in the example with Morgan Freeman, where Piers claims common knowledge and empathy with the guest, thereby expressing his solidarity with the interlocutor:

MORGAN to FREEMAN: How do you get on with your ex these days? I've been through a divorce. It's not easy with the actual process.

Last but not least, our next strategy in the second group is joke. As Brown and Levinson (1987) note that "since jokes are based on mutual shared background knowledge and values, they may be used to stress that shared background or those shared values as well as being a basic positive-politeness technique for putting interviewee at ease" (Brown \& Levinson, 1987, p. 124).

Note the example:

MORGAN to BEYONCE: Any truth to the rumor that you and Jay-Z are having joint pyramids built to be remembered? This is rumor?// BEYONCE: That's a good one./MORGAN: I just made it up.//BEYONCE: OK. (LAUGHTER).

Examining these verbal exchanges, we can say that joking puts interviewee at ease and creates a friendly atmosphere between two parties, thereby satisfying the positive image of the interactants

3. The third group involves strategies that include both the interviewer and the interviewee in the activity, thus emphasizing the interaction and cooperation between the two parties in the process of communication and creating the atmosphere of shared identity. This can be manifested by using an inclusive 'we' form, when S means 'you' or 'me':

MORGAN to WINFREY: How many people do you absolutely, 100 percent trust? Are they people that we would know?

Or as in the example with Simon Cowell:

MORGAN to SIMON COWELL: You've never got married. But now we 're on the verge of the romantic apocalypse, aren't we? You are now heading to the altar?

Morgan may call upon the cooperative assumptions and thereby redress FTAs by using the following expressions: Let's go private ... // / Let's start with ... /// Let's have a burst, and the like. 
We also refer to the third group strategies that claim in-group membership with the interlocutor, which are expressed by in-group usages of address forms, dialect, jargon, slang or ellipsis.

Morgan refers to the interviewee by name:

MORGAN to LONGORIA: Eva, how are you?

MORGAN to FREEMAN: Because I've always felt with you, Morgan

MORGAN to WINFREY: Oprah, what is it you do best?

Addressing by name, Morgan wants to show that they are on equal footing with the interlocutor, thereby denying the possible social distance from the interlocutor. Besides, it is important to emphasize that guests accept that by replying to the host in the same way. Interestingly enough, the communicative effect created by applying this strategy seems to be very favorable for the further conversation.

To this group we also refer the following expressions: come on; talk me through it, feel free to share and the like, which are typical of very intimate friendly discourse and whose communicative goal is to claim membership of the "common" group, thus creating an informal, relaxed atmosphere favourable for heartwarming communication. Note the following:

MORGAN to THERON: Let's have a burst. Come on. I love it if you speak African to me.

MORGAN to THERON: Charlie, come on Charlie// So, come on, dig in with me.// Come on, let's get you on the therapist couch here;

MORGAN to FREEMAN: Talk me through it. // But look me in the eye and tell me this;

MORGAN to WINFREY: Feel free to share / / Oh, please, tell me the truth / / Come on, humor me.

Consequently, we conclude that positive politeness is aimed at maintaining a positive image of the interlocutor. By demonstrating it, the interviewer expresses his solidarity, interest, positive attitude to the interviewer, thus creating the atmosphere of "common" identity favorable for frank conversation.

\section{Analysis: linguistic realization of negative politeness strategies}

On the other hand, Brown and Levinson (1987) state that negative politeness is "redressive action addressed to the addressee's negative face: his want to have his freedom of action unhindered and his attention unimpeded. It is 'the heart' of respect behavior" (Brown \& Levinson, 1987, p. 129). Negative politeness stands for a well designed set of linguistic strategies for FTA redress; and aims to demonstrate the recognition of the interlocutor's independence, personal autonomy, to convince the interlocutor of the absence of intent of the interviewer to "infringe» on his "territory». Brown and Levinson refer conventional indirectness, hedges on illocutionary force, polite pessimism, the emphasis on H's relative power to negative politeness realizations (Brown \& Levinson, 1987, p. 130).

On the basis of negative politeness strategies suggested by P. Brown and S. Levinson (1987) and from our personal observations, we identify the following strategies of negative politeness in Piers Morgan's communicative behavior:

\section{1) Be conventionally indirect}

Evidently, we find a large number of questions in Piers Morgan's interviews as in the example:

MORGAN to LONGORIA: Could you give me your hand, please?// Could you ever go out with a man with a soft handshake? // Would you get married again?

Which can be explained in two ways: on the one hand, the genre of the interview requires the "question-answer" format, on the other hand Piers Morgan wants to create a favourable atmosphere, trying to give maximum freedom of action to the interlocutor. 
According to Larina (2009), direct communicative style is not specific to the English interpersonal communication, so the preference is given to indirect one, which manifests itself in different communicative situations: when requesting information, expressing opinions, requesting, in the invitation, etc. Therefore, indirect questions such as (I wonder... / I'm wondering...) abound in Piers Morgan's utterances.

Also, we can observe the strategy of being conventionally indirect, when Morgan expresses himself indirectly through the affirmative sentence, in order not to ask the guest directly. Note the following taken from Piers Morgan Live with Beyonce, when he wants to ask her who taught her to be exactly the way she is.

MORGAN to BEYONCE: And it seemed to me they taught you about the importance of when you get there to be humble, to not lose a sense of who you are.

What is more, we can see here how Morgan makes his opinion more subjective with the phrase it seemed to me, expressing himself through the prism of his own perception, thus reducing the possibility of "infringing" on the interlocutor.

\section{2) Question, hedge}

By 'hedges' we understand words or phrases that diminish the force of a speech act; as Larina (2009, p. 95) notes this strategy is aimed at "creating obstacles». Note the examples:

MORGAN to LONGORIA: I mean, my God, woman, there's no end to your talents.// $\underline{I}$ mean I can tell just by talking to you. I don't know.

MORGAN to THERON: You obviously were raised a South African and you came to L.A. with a broad South African accent. And you quite consciously went and taught yourself how to speak in an American accent, right?

MORGAN to THERON: $\underline{I \text { mean }}$ you always choose these challenging roles. I mean they're always quite edgy, the ones that I've seen. They're always a little bit dangerous. I mean, you know, you take risks. I like that about you as an actress. There's never the safe one, is there?

MORGAN to WINFREY: I suppose the contradiction is that oddly you are in a position with this network where you are possibly least in control.

With the help of this strategy, Morgan softens his straightforwardness requirement so that:

3) to be pessimistic

As Brown and Levinson (1987) state "this strategy gives redress to H's negative face by explicitly expressing doubt that the conditions for the appropriateness of S's speech act obtain." Linguistically this strategy may be realized by means of negative usages ( I don't think; I don't suppose; I'm not sure), the use of negative with a tag, the use of the subjunctive (could; would; might), pessimistic hedges (perhaps, probably, etc.) (Brown \& Levinson, 1987, p. 173 - 175).

MORGAN to THERON: What is the correct South African, dare I say it, African way of pronouncing this?

MORGAN to LONGORIA: Because we probably have different audiences. // We have a lot to talk about. I don't think an hour covers it.

MORGAN: I'm not sure whether you want it.

\section{4) to minimize the imposition}

Brown and Levinson (1987) state: "Don't assume Hearer is able, willing to do A', 'assume he is not likely to do A"” (Brown \& Levinson, 1987, p. 176). Expressions that minimize the imposition are expressions like: a tiny little bit, a little, a bit, etc. For instance:

MORGAN to THERON: I mean you always choose these challenging roles. I mean they're always quite edgy, the ones that I've seen. They're always a little bit dangerous. 
MORGAN : What is it - is your wall of shame we have here or hall of fame, whatever you call it. Here we can see that Piers uses this strategy in order to make minimal threat by asking whether the guest wants to answer or not.

\section{5) to apologize}

According to Brown and Levinson (1987), by apologizing for doing FTA, the interviewer can indicate his reluctance to impinge on interviewee's negative face and thereby partially redress that impingement. The interviewer may show that he is reluctant to impinge on $\mathrm{H}$ with the use of hedges (discussed above) or by means of expressions such as following: I hope you don't mind me saying this, but ...; I don't want to bother you, but ..., etc (Brown \& Levinson, 1987, p. 187). Note the following taken from Piers Morgan Live.

MORGAN to GOLDBERG: What flaws do you have? If you don't mind me saying too obvious. By such an expression Morgan communicates reluctance to do FTA or to put it another way, with apology for interfering Morgan gives the interviewee in the words of Brown and Levinson (1987) "an 'out', a face-saving line of escape", permitting Goldberg to feel that her response is not coerced.

Note the example with Oprah, when he touches on a very unpleasant topic for her and judging from what she says starts to justify himself by apologizing.

OPRAH: So, don't even try to go there.//MORGAN: I haven't even dared to go there. I wasn't even going to mention it.

\section{6) to impersonalize $S$ and $H$}

One way of indicating that $\mathrm{S}$ doesn't want to impinge on $\mathrm{H}$ is to phrase the FTA as if the agent were other than $\mathrm{S}$, or at least possibly not $\mathrm{S}$ or not $\mathrm{S}$ alone, and the addressee were other than $\mathrm{H}$, or only inclusive of $\mathrm{H}$. This results in a variety of ways of avoiding the pronouns ' $\mathrm{I}$ ' and 'you', or may be manifested by point-of-view distancing (Brown \& Levinson, 1987, p. 190). One set of mechanisms involves manipulating the expression of tense to provide distancing in time. As the tense is switched from present into past, the interviewer distances himself from the here and now. Note the following: MORGAN: I was just curious... .

\section{7) State the face threatening act (FTA) as a general rule}

As Brown and Levinson (1987) note "one way of dissociating S and $\mathrm{H}$ from the particular imposition in the FTA, and hence a way of communicating that S doesn't want to impinge but is merely forced to by circumstances, is to state the FTA as an instance of some general social rule, regulation, or obligation" (Brown \& Levinson, 1987, p. 206).

MORGAN to FREEMAN: And also if you're in the business where your appearance is part of your business, you have to be vain. And you have to have an ego. You have to walk on set and believe you're pretty good.

The imposition itself is represented as a case of a general obligation and the interviewer merely draws attention to the existence of common practice in the show business which is independent of $\mathrm{H}$.

Thus, we have a vivid example of how Morgan makes distance from the direct question if Freeman is vain, where the FTA is stated as an instance of some common practice. According to Larina, this strategy is mainly manifested by such expressions as: have to and to be supposed to, which enables the interviewer to make the expression of obligation weaker (Laryna, 2009).

It is noteworthy that the strategies of negative politeness are closely interwined, that is why sometimes they are difficult to differentiate within a single utterance. By means of questions interviewer can express himself indirectly, at the same time he gives the interviewee the right 
to act freely as well as he doubts the performance of the act by means of different pessimistic hedges or other lexical devices. Besides, what seems obvious is that more than one strategy is realized within each utterance.

\section{Conclusion}

Consequently, one of the conclusions that may be drawn from our study is that Piers Morgan's communicative behavior tends to combine both strategies of positive and negative politeness though, from our careful observations, with the evident predominant use of positive politeness strategies. Therefore, it seems reasonable to assume that those strategies of positive politeness used contribute to (a) closing the social distance between interlocutors; (b) putting the interviewees at ease by creating friendly atmosphere to allow them to 'open up'. However, one issue remains contentious that positive politeness strategies used by Piers Morgan occasionally come to serve quite different purpose, due largely to their striking expression, those strategies may even turn to FTAs as they may put interviewees off. Equally important is the fact, that during the interview Piers Morgan uses FTAs, as if he were trying to"catch his guests off guard". At first, he meets the wants of their positive face and totally unexpectedly he switches to the taboo topics. Most importantly, according to Larina, among the communicative prohibitions of the English culture, interjection is totally inappropriate and is considered to be the most flagrant violation of communication. Observing Piers Morgan's television interviews, we can notice a constant interjection, unexpected interruption in the middle of conversation, the imposition of the guest's point of view, illogical remarks or conscious ignorance of the guest's replicas, which makes it a complete list of the FTAs.

However, we tend to believe that such an interesting combination of politeness strategies and FTAs can bring Piers Morgan professional success in the USA.

Moreover, the conclusions that we draw from the study are the following:

1. Politeness theory seems to be relevant for the study of communicative behavior of the interviewer in the discourse of television interviews;

2. Positive politeness strategies prevail in communicative behavior of the interviewer;

3. It seems reasonable to assume that the predominant politeness strategies determine success or failure of the interviewer;

4. More than one strategy is realized with each utterance;

5. They (strategies) are all strategic to Piers Morgan's extralinguistic goal of having a good interview.

\section{References}

Brown, P. \& S. Levinson. (1987). Politeness: Some Universals in Language Usage. Cambridge: CUP.

CNN Transcripts. Piers Morgan Tonight (n.d.). Retrieved from http://transcripts.cnn.com.

Goffman, E. (1967). Interaction Ritual: Essays on Face-To-Face Behavior. Garden City, NY: Anchor Books.

Larina, T. V. (2009). Katehoryya Vezhlyvosty y Styl' Kommunykacyy: Sopostavlenye Anhlyjskix y Russkix Lynhvo-kul'turnyx Tradycyj (The Category of Politeness and the Style of Communication: Comparison of English and Russian Cultural Traditions). Moskow: Rukopysnыe pamyatnyky Drevnej Rusy.

Piers Morgan Live. (n.d.). Retrieved from http://en.wikipedia.org/wiki/Piers_Morgan_Live . Watts, R. J. (2003). Politeness. Cambridge: Cambridge University Press. 


\section{ПРАГМАТИКА ВВІЧЛИВОСТІ АМЕРИКАНСЬКОМУ В ТЕЛЕВІЗІЙНОМУ ТОК-ШОУ: PIERS MORGAN LIVE}

\section{Марія Федина}

Львівський національний університет імені Івана Франка вул. Університетська 1, Львів, 79000, Україна mariya.fedyna@gmail.com

У даній розвідці автор розглядає категорію мовленнєвої ввічливості та комунікативні стра-тегії ввічливості на прикладі американського ток-шоу "Piers Morgan Live" i намагається проаналізувати стиль комунікації Пірса Моргана через призму теорії ввічливості П. Браун та С. Левінсона та поняття обличчя Е. Гофмана.

Ключові слова: обличчя, негативне обличчя, мовленнєві акти-загрози (обличчю співрозмовника), мовленнєві стратегії, (не)ввічливість. 